\title{
Cashew Nuts Production and Marketing among Farmers in Ugwolawo District, Kogi State, Nigeria
}

\author{
Agada*, Mary Ojotule and Sule, Etemayi Mustapha \\ Department of Agricultural Extension and Communication, Federal University of Agriculture, P.M.B. \\ 2373, Makurdi, Nigeria \\ *Corresponding Authors: Agada, Department of Agricultural Extension and Communication, Federal \\ University of Agriculture, P.M.B. 2373, Makurdi, Nigeria
}

\begin{abstract}
This study assessed production and marketing of cashew nuts by farmers in Ugwolawo District, Kogi State, Nigeria. Data for the study were collected from 105 respondents using a structured interview schedule. Data collected were analyzed using both descriptive (percentages and mean scores) and inferential statistics (Spearman's rank correlation). The results revealed that majority of cashew farmers were educated $(68.6 \%)$ men $(76.0 \%)$, who inherited (93.3\%) cashew farm land. On average, respondents were 48.9 years of age, had cashew farming experience of 10.6 years, output of $2954.8 \mathrm{~kg}$ and cashew annual income of \#261.766.67. Farmers were aware and used cashew production agronomic practices such as seed selection $($ Aware $=95.2 \%$; Used $=91.4 \%)$; land preparation $($ Aware $=98.1 \%$; Used $=98.1 \%)$; transplanting (Aware $=83.8 \%$; Used $=62.9 \%) ;$ manual weeding (Aware $=100.0 \%$; Used $=99.0 \%) ;$ pruning $($ Aware $=96.2 \%$; Used $=89.5 \%$ ); and harvesting (Aware $=100.0 \%$; Used $=100.0 \%$ ). The level of cashew nuts production was moderate in 2011 (40.0\%); 2012 (55.2\%), 2013 (63.8\%) and 2014 (42.9\%) but high in 2015 (46.7\%). Majority $(89.7 \%)$ marketed their produce through small-scale/retailers (89.5\%) and wholesalers (67.6\%). All respondents (100.0\%) sourced information from fellow farmers and buying agents. The Spearman's rank correlation result showed a significant relationship between awareness and use of cashew agronomic practices by farmers at $5 \%$ probability level $(t=0.0198)$. It also revealed a significant relationship between respondents' use of cashew agronomic practices and level of production at 5\% alpha level $(t=0.0405)$. Farmers experienced various constraints in cashew nuts production and marketing. The study concludes that production of cashew nuts was moderate, but with low yields due to a plethora of constraints, including non-utilization of some yield enhancing technologies and poor access to viable markets. It is recommended that farmers should be encouraged to use improved cashew production practices for enhanced production and improved income. Also, government should link producers to viable markets and processing industries to enable them have good return on their investments.
\end{abstract}

Keywords: cashew nuts, production, marketing, farmers, Kogi State

\section{INTRODUCTION}

Cashew (Anarcadiumoccidaentale) is a drought resistant crop that can grow successfully in areas with a distinct dry season or where the annual rainfall is as low as $50 \mathrm{~cm}$. It can also grow well in areas with high level of rainfall as much as $350 \mathrm{~cm}$ annually provided the soil is well drained [1]. It is a tree crop of economic importance to Nigeria and other tropical countries [2].

Cashew is reportedly ranked third in world production of edible nuts that are traded globally [2]. The annual world production of cashew nuts was about 3,186,039 tons and Nigeria was rated the second among the top ten producers with 660,000 tons after Vietnam as the highest producer with 961,000 tons [3]. The introduction of Brazilian cashew biotype with improved and desirable nuts and quality characteristics by the Cocoa Research Institute of Nigeria (CRIN) has further increased the popularity of the crop and the spread in Nigeria [4].The contribution of Kogi State to the nation's production is about 30\% annually, while the Eastern part of the State accounted for about $60 \%$ of the State's production [5]. The average yield of the nuts of a mature cashew tree ranges from $7-11 \mathrm{~kg}$ per annum [5]. In Nigeria, cashew nuts exports represent 7- 8\% of non-oil export earnings. The estimated export value varies from US\$25- 35 million annually, and supplements the income of about 50,000 farmers and an additional 55,000 people who are employed down its value chain [6,7]. Nigeria tops the countries that produce the best cashew nuts, followed by India, Cote $\mathrm{d}$ Ivoire and Philippines [8].

Marketing is one of the vital aspects of agriculture, since agriculture entails the production of goods and services, production is said not to be completed until the commodity produced reaches the final 
consumer [5]. There has been a tremendous price appreciation of Nigerian cashew nuts in the international markets with tons of cashew nuts, which sold for N24,753.00 in 1993 rising to N180,011.00 in 2003 [9, 10]. However, price of raw cashew nuts dropped from N300, 00.00 (\$833.00) in 2018 to $\$ 1,100$ in 2019, signally 34\% drop in price from 2018 [8]. The marketing of cashew is mostly affected by price instability due to the seasonality nature of its production and lack of storage facilities [5].

Cashew crop constitutes a source of income, employment and raw materials for the producing nations [11]. More than $65 \%$ of farming families who are smallholder farmers all depend on the crop as a major source of income in Nigeria [12]. Cashew is grown throughout Nigeria but the cultivation is centralized primarily in the south and middle belt regions in smallholder farms and plantations [1].

The major products from cashew are dried cashew nuts, cashew karnels (nuts), which are ready to eat products, cashew nut shell liquid (CNSL), cashew juice, cashew apple candy or jam and cashew apple wine [1]. Ripe cashew apple is sweet and rich in vitamin $\mathrm{C}$ and sugar, its nuts contain the fat soluble vitamins $\mathrm{A}, \mathrm{D}, \mathrm{K}$ and minerals such as calcium, phosphorous and iron, which are required for the healthy growth of human body [2]. It was mainly used in afforestation schemes for the control of erosion in the former eastern Nigeria [10].

The problems of cashew production include; old trees, deforestation, low yield varieties, dominance of small holdings and wild varieties, land acquisition, high cost of inputs, climatic conditions, diseases and pests, fire outbreaks, post-harvest losses, infrastructural constraints, poor qualities, market price of the product and the competition amongst the local buying agents [1]. Inability of farmers to afford the application of inorganic fertilizers coupled with its negative effects on the environment is also a problem facing cashew production [13].

The problems facing cashew marketing include: unavailability of labour, lack of processing technology, high cost of production, unstable market system, high interest rate, low funding, inadequate infrastructural facilities such as rural roads, electricity, water supply and poor exit services [14].

Several studies have been carried out on cashew production and marketing in the past. For instance, work was carried out on constraints in cashew production among cashew farmers in southwestern Nigeria [15]. Also, there was a study on socio-economic factors affecting use of information sources among cashew farmers in Niger State, Nigeria [16] and another study on profitability and structural analysis of cashew nuts market in Oyo State, Nigeria [17]. Similarly, an analysis on the profitability of value addition of cashew farming households was conducted in Nigeria [18] as well as an assessment of cashew processing for economic development in Nigeria [5]. This study is different from the earlier ones as it assessed both the production and marketing of cashew nuts in the study area. Moreover, none of these studies was conducted in Ugwolawo District, Kogi State, Nigeria, hence this study became imperative. The study would create awareness among producers of the available improved cashew production technologies and marketing channels for the produce for enhanced productivity, improved income and livelihood.

The specific objectives were: (i) describe the socio-economic characteristics of the respondents; (ii) determine farmers' awareness of cashew production agronomic practices; (iii) ascertain farmers' use of cashew production agronomic practices; (iv) ascertain the level of cashew nuts' production by the respondents in the last five years; (v) identify the marketing channels for the sale of cashew nuts; (vi) identify the sources of information on cashew nuts production and marketing; and (vii) identify the constraints militating against the production and marketing of cashew nuts in the study area.

The study hypothesized that: $\left(\mathrm{H}_{\mathrm{O} 1}\right)$ there is no significant relationship between awareness of cashew production agronomic practices and use by the respondents; and $\left(\mathrm{H}_{\mathrm{O} 2}\right)$ there is no significant relationship between the use of cashew agronomic practices and level of production by the respondents.

\section{MeTHOdOLOGY}

\subsection{The Study Area}

The study was carried out in Ugwolawo District, Kogi State, Nigeria. Ugwolawo is the headquarters of Ofu Local Government Area and is situated in Kogi East Senatorial District. Ofu Local Government Area is located on latitude $7^{\circ} 20^{\mathrm{I}} \mathrm{N} 7^{\circ} 05^{\mathrm{I}} \mathrm{E}$ and longitude $7.333^{\circ} \mathrm{N} 7.083^{\circ}$ ( Ofu Local Government, 2015). The LGA has a population of about 192,169 inhabitants [19]with a land mass of 
about 8,747.5 square kilometres. The Local Government has a number of tourist delights namely; UlokoAmo Water Falls in Ofokopi, Ugbakoji Hills in Itobe, Egane Water Falls and Ofakete Natural Bridge, Alo Natural Tunnel and Ojuwo Mission Settlement at Ugwolawo. The main occupation of the inhabitants is farming and the major crops grown include maize, cowpea, millet, groundnut, and melon, while the tree crops are cashew, citrus, mango, and Avenger senegalensis. The inhabitants also keep livestock such as goats, poultry and sheep [20].

\subsection{Population and Sampling Procedure}

The population for the study comprised all cashew producers in Ugwolawo District of Kogi State. Ugwolawo District is made up of 4 Council Wards namely; Aloji, Ugwolawo 1, Ugwolawo 2 and Ochadamu. Multistage sampling procedure was employed for this study. Firstly, Ugwolawo Ward 1 was purposively selected due to its predominance in cashew production in the district. Secondly, a census of all cashew producers in the ward was conducted and six (6) villages in the ward were selected out of eighteen (18) villages that make up the ward using simple random sampling technique. A sampling frame was developed for each of the villages, and using a proportional allocation of fifty percent $(0.5 \%)$ across board, a total sample size of 105 respondents was used for the study [(Ugwolawo (30); Ahi (15); Ofo-olijinwa (15); Ogokolo (25); Agwale (10); and Ukpotume (10)]. Data were collected using a well-structured questionnaire distributed to individual cashew farmers in the selected villages.

\subsection{Data Analysis}

Data for the study were analyzed using both descriptive and inferential statistics. Descriptive statistics such as percentage, frequency and mean scores were used to analyze all the research objectives, while Spearman's rank correlation was used to analyze the null hypotheses 1 and 2.

\section{RESULTS AND DISCUSSION}

\subsection{Socio-Economic Characteristics of the Respondents}

The socio-economic characteristics of the respondents are depicted in Table 1. The results showed that majority (76.2\%) of cashew farmers in Ugwolawo District were male, while $23.8 \%$ were female. This implies that most of the cashew farmers in the study area were predominantly male. The finding agrees with the studies which indicated that about $84.5 \%, 93.3 \%, 78.4 \%$ and $91.7 \%$ of the respondents respectively were male $[14,16,17,21]$. The dominance of male over female in cashew nuts production observed in the study area could be attributed to the patriarchal nature of the society which gives the right of land ownership to the male members of the household, thereby making it difficult for the female members to invest in cashew cultivation.

Findings on age of cashew farmers revealed that about $43.9 \%$ of the respondents were within the age bracket of 41-60 years, 29.5\% were within the age range of 21-40 years, while about $25.7 \%$ were above 60 years with a mean age of 48.7 years. This implies that most of the cashew farmers in the study area were ageing since a greater percentage $(69.8 \%)$ was above 40 years. The finding of this study corroborates the report that most $(64.0 \%)$ cashew farmers in Ruangwa District, Tanzania were above 40 years [22]. The result also agrees with the studies which found the mean age of cashew farmers to be 41.0 years and 46.5 years respectively $[16,23]$. The study however, disagrees with the finding that the average age of cashew farmers in Kogi State was 56 years [18]. The older the farmer becomes the more experienced in farming activities but older farmers could resist new information on improved cashew production technologies since they are avert to new ideas.

The results on level of education revealed that majority $(68.6 \%)$ of the respondents were educated with about $26.7 \%$ having secondary and primary education each while about $15.2 \%$ attained tertiary education. This implies that majority of the cashew farmers in the area attained one level of education or another. Other studies found that $53.3 \%, 61.4 \%, 52.5 \%$ of the cashew farmers were non-literate $[14,22,24)$. Education can enhance adoption of improved cashew agronomic practices and knowledge of cashew marketing. However, this study found that high literate level did not enhance the adoption of improved cashew technologies as less than half of the technologies were used by farmers.

The finding on years of cashew farming showed that a little above thirty two percent $(32.4 \%)$ of the respondents had about 1-10 years of cashew farming experience, $29.5 \%$ had from 11-20 years, $22.9 \%$ had 21-30 years and $15.2 \%$ had above 30 years with mean cashew farming experience of 10.64 years for the study area. This implies that majority (77.7\%) of the farmers in the study area have 
beenfarming cashew for a long time. Similar studies showed that $70.0 \%$ and $73.3 \%$ respectively of the farmers had long time experience in cashew production [14, 23].. Experience could influence farmers' productivity and their ability to manage any constraint in cashew farming and marketing.

On sources of cashew farm land, majority (93.3\%) of the respondents reported getting their land through inheritancewhile $1.9 \%$ got it by purchase, $1.0 \%$ had theirs through leasing and $3.8 \%$ through the community. This implies that majority of the farmers got their cashew farm lands by inheritance. An earlier study [16] found that most (71.1\%) cashew farm lands were inherited. Although inherited land could enhance the cultivation of tree crops, this may be at a low scale due to land fragmentation arising from large number of beneficiaries.

The results on cashew nuts output showed that close to half (48.6\%) of the respondents had an output of $1000-2000 \mathrm{~kg}, 22.9 \%$ had from $2100-4000 \mathrm{~kg}, 15.2 \%$ had more than $6000 \mathrm{~kg}$, while a few $(13.3$ $\%$ ) had about $4100-6000 \mathrm{~kg}$ of cashew nuts in the previous year, with an average yield of 2,954.76 $\mathrm{kg} / \mathrm{ha}$. This implies that generally, farmers had low yield of cashew nuts in the study area. The low yield could be attributed to low usage of some improved production practices such as fertilizer, improved varieties and pesticides.

Results on income from sale of cashew nuts indicated that about $32.4 \%$ of the respondents earned about 100,000 and below from cashew farming in the previous year, $5.7 \%$ earned $\$ 401,000 \$ 500,000,10.5 \%$ earned about $\$ 201,000-\$ 300,000,12.4 \%$ earned from $\$ 301,000$ $\$ 400,000$ and $16.2 \%$ earned $\$ 101,000-\$ 200,000$ with mean annual cashew income of $\$ 261,766.67$ only. This implies that generally, the amount of money derived from cashew farming in the study area was moderate. Earlier studies reported low income from cashew farming averaging $\$ 22,955.55$ and $\$ 77,979.17$ respectively $[16,25]$. The reasonable rate of return despite low output could be attributed to high price at the international market at the time of sales. Cashew nuts production and marketing is a good source of income for farmers, and this is mostly utilized in paying children's school fees and acquiring household equipment and mobility. It is expedient, therefore, for governments at the local and state levels to encourage farmers to sustain the production of the crop in order to improve their income and livelihood.

Table 1. Socio-Economic Characteristics of the Respondents ( $n=105$ )

\begin{tabular}{|l|l|l|l|}
\hline Characteristics & Frequency & Percentage & Mean \\
\hline Sex & & & \\
\hline Male & 80 & 76.2 & \\
\hline Female & 25 & 23.8 & \\
\hline Age (years) & & & \\
\hline $21-40$ & & 29.4 & 48.74 \\
\hline $41-60$ & & 43.9 & \\
\hline$>60$ & 27 & 25.7 & \\
\hline Level of Education & & & \\
\hline Non Formal Education & 33 & 31.4 & \\
\hline Primary & 28 & 26.7 & \\
\hline Secondary & 28 & 26.7 & \\
\hline Tertiary & 16 & & 2954.7 \\
\hline Cashew Output (kg/ha) & & 32 & \\
\hline $100-2000$ & 51 & 46 & \\
\hline $2001-4000$ & 24 & 22.9 & \\
\hline $4100-6000$ & 14 & 13.3 & \\
\hline$>6000$ & 16 & 15.2 & \\
\hline $\begin{array}{l}\text { Cashew Farming Experience } \\
\text { (years) }\end{array}$ & & & \\
\hline $1-10$ & 34 & 32.4 & \\
\hline $11-20$ & 31 & 29.5 & \\
\hline $21-30$ & 24 & 22.9 & \\
\hline$>30$ & 16 & 15.2 & \\
\hline Sources of Cashew Farm Land & & 93.3 & \\
\hline Family & 98 & & \\
\hline
\end{tabular}


Cashew Nuts Production and Marketing among Farmers in Ugwolawo District, Kogi State, Nigeria

\begin{tabular}{|l|l|l|l|}
\hline Purchase & 2 & 1.9 & \\
\hline Lease & 1 & 1.0 & \\
\hline Others & 4 & 3.8 & \\
\hline Income from Cashew (N) & & & \\
\hline$\leq 100,000$ & 34 & 32.4 & 261766.67 \\
\hline $101,000-200,000$ & 17 & 16.2 & \\
\hline $201,000-300,000$ & 11 & 10.5 & \\
\hline $301,000-400,000$ & 13 & 12.4 & \\
\hline $401,000-500,000$ & 6 & 5.7 & \\
\hline$>500,000$ & 24 & 22.9 & \\
\hline
\end{tabular}

\subsection{Awareness of Agronomic Practices by Cashew Farmers in Ugwolawo District}

Table 2 shows cashew farmers' awareness of agronomic practices. The results indicated that out of the thirteen (13) agronomic practices listed, majority of the respondents were aware of eleven (11). These included improved varieties $(58.1 \%)$, seed selection $(100.0 \%)$, land preparation $(100.0 \%)$,nursery preparation (52.4\%), transplanting (83.8\%), herbicides application (82.0\%), manual weeding $(100.0 \%)$, pruning $(96.2 \%)$, intercropping $(82.2 \%)$, harvesting $(100.0 \%)$ and storage $(89.5 \%)$. However, most farmers reported they were not aware of pesticide application $(60.0 \%)$ and fertilizer application (67.9\%). This implies that most farmers were aware of improved agronomic practices of cashew production.

Table 2. Distribution of Respondents according to Awareness of Agronomic Practices in Cashew Production in Ugwolawo District, Kogi State $(n=105)$

\begin{tabular}{|l|l|l|}
\hline Agronomic practices & Frequency* & Percentage \\
\hline Improved varieties & 61 & 58.1 \\
\hline Seed selection & 105 & 100.0 \\
\hline Land preparation & 105 & 100.0 \\
\hline Pesticide application & 42 & 40.0 \\
\hline Nursery preparation & 55 & 52.4 \\
\hline Transplanting & 88 & 83.8 \\
\hline Fertilizer application & 41 & 39.0 \\
\hline Manual weeding & 105 & 100.0 \\
\hline Herbicide application & 87 & 82.0 \\
\hline Pruning & 101 & 96.2 \\
\hline Intercropping & 87 & 82.9 \\
\hline Harvesting & 105 & 100.0 \\
\hline Storage & 94 & 89.5 \\
\hline
\end{tabular}

*Multiple responses recorded

\subsection{Use of Agronomic Practices by Cashew Farmers in Ugwolawo District}

Results on use of improved cashew agronomic practices are depicted in Table 3 . The results showed that majority of the respondents used 7 out of the 13 agronomic practices. The 7 practices used by farmers included harvesting (100.0\%), manual weeding (100.0\%), seed selection (91.4\%), land preparation (100.0\%), pruning (89.5\%), transplanting (62.9\%) and storage of cashew nuts $(84.8 \%)$. Pruning is an important cultural practice in cashew production. This finding is in line with the work carried out in Wenchi Municipality, Ghana which reported that a greater percentage $(52.9 \%)$ of cashew farmers pruned their cashew [24]. The finding also confirms the assertion that manual weeding is one of the major issues in cashew production as weeds can prevent the seedling from growing [26]. The practices most farmers did not use were improved varieties (79.0\%) which concurs with an earlier finding that most $(68.6 \%)$ of the respondents used local varieties in cashew production [24]. Furthermore, practices such as pesticide application (86.7\%), nursery preparation (93.3\%), fertilizer application (83.3\%), herbicides application (51.4\%) and intercropping (82.9\%) were not used by most respondents. Although most farmers were aware of improved agronomic practices of cashew farming; the use of some of these practices was low, probably due to ignorance arising from lack of information, lack of access to the technologies and lack of finances to purchase the vital production inputs. 
Table 3. Distribution of Respondents according to Use of Agronomic Practices in Cashew Production in Ugwolawo District, Kogi State $(n=105)$.

\begin{tabular}{|l|l|l|}
\hline Agronomic practices & Frequency* & Percentage \\
\hline Improved varieties & 22 & 21.1 \\
\hline Seed selection & 96 & 91.4 \\
\hline Land preparation & 105 & 100.0 \\
\hline Pesticide application & 14 & 13.3 \\
\hline Nursery preparation & 07 & 6.7 \\
\hline Transplanting & 66 & 62.9 \\
\hline Fertilizer application & 17 & 16.2 \\
\hline Manual weeding & 105 & 100.0 \\
\hline Herbicide application & 51 & 48.6 \\
\hline Pruning & 94 & 89.5 \\
\hline Intercropping & 18 & 17.1 \\
\hline Harvesting & 105 & 100.0 \\
\hline Storage & 105 & 100.0 \\
\hline
\end{tabular}

*Multiple responses recorded

\subsection{Level of Production of Cashew Nuts by the Respondents}

Results on the mean production level of cashew nuts by farmers in the study area are presented in Table 4. The results indicated that cashew nuts' production was moderate in $2014(\bar{x}=2.36)$ and 2015 $(\bar{x} 2.39)$ but low in 2011 ( $\bar{x}=1.93), 2012(\bar{x}=1.95)$ and $2013(\bar{x}=1.98)$. Finding revealed that, overall the level of production of cashew nuts in the study area for the year under review (2011-2015) was low. The low level of cashew nuts production could be attributed to the non-utilization of close to half of the improved agronomic practices such as improved varieties (79.0\%), pesticide application $(86.7 \%)$, nursery preparation $(93.3 \%)$, fertilizer application $(83.3 \%)$, herbicides application $(51.4 \%)$ and intercropping $(82.9 \%)$. Use of these production practices could increase farmers' production and productivity and enhance their income, thereby improving their standard of living.

Table4. Distribution of Respondents according to Level of Cashew Nuts Production (2011-2015)

\begin{tabular}{|c|c|c|}
\hline \multirow{2}{*}{ Year } & \multicolumn{2}{|c|}{ Level of Cashew Nuts Production } \\
\cline { 2 - 3 } & Mean & Standard Deviation \\
\hline 2015 & 2.39 & 0.628 \\
\hline 2014 & 2.36 & 0.667 \\
\hline 2013 & 1.98 & 0.604 \\
\hline 2012 & 1.95 & 0.671 \\
\hline 2011 & 1.93 & 0.775 \\
\hline
\end{tabular}

Key: High= 2.50-3.00; Moderate = 2.00-2.49; Low $=<2.00$

\subsection{Marketing Channels for Cashew Nuts in Ugwolawo District, Kogi State}

Table 5 shows the channels for marketing cashew nuts in the study area. The results showed that majority $(89.5 \%)$ of the respondents sell cashew nuts to retailers at the nearby markets, about $67.6 \%$ sell to the wholesalers, while $17.1 \%$ and $3.8 \%$ sell their produce at the farm gates and to bulk assemblers respectively. This implies that majority of cashew farmers in the study area sell cashew nuts through the small-scale/retailers and wholesalers' marketing channels. This finding indicates that all the respondents (100.0\%) purchased cashew nuts directly from cashew farmers and most (98.3\%) of them further sold to other wholesalers and retailers in the market chain [17]. This could influence the pricing of cashew nuts in the study area as the small-scale/retailers and wholesalers buy at cheaper prices from the cashew farmers, thereby making more profits than the producers.

Table 5. Percentage Distribution of Respondents according to Marketing Channels for Cashew Nuts in Ugwolawo District, Kogi State $(n=105)$

\begin{tabular}{|l|l|l|}
\hline Marketing Channels & Frequency* & Percentage \\
\hline Producer/farm gate & 18 & 17.1 \\
\hline Small-scale/retailers & 94 & 89.5 \\
\hline
\end{tabular}




\begin{tabular}{|l|l|l|}
\hline Bulk assemblers & 4 & 3.8 \\
\hline Wholesalers & 71 & 67.6 \\
\hline
\end{tabular}

*Multiple responses recorded

\subsection{Sources of Information on Cashew Nuts' Production and Marketing}

Table 6 shows the percentage distribution of farmers according to information sources for production and marketing of cashew nuts. The results indicated that all the respondents sourced information on cashew nuts' production and marketing from fellow farmers (100.0\%) and cashew buying agents $(100.0 \%)$. Other sources of information for farmers were radio (66.7\%), television (2.9\%), extension agents $(2.9 \%)$ and village leaders $(19.0 \%)$. This implies that the most available sources of information on cashew nuts' production and marketing were fellow cashew farmers, cashew buying agents and radio. It also showed that cashew farmers had low contact with extension agents in terms of information source for cashew nuts' production and marketing. The finding a similar study in Nigeria indicated that cashew farmers sourced information from their fellow farmers [27]. This finding has implication for extension workers to work hard at information dissemination on improved practices and marketing strategies to cashew farmers in the study area.

Table 6. Percentage Distribution of Respondents according to Information Sources on Cashew Nuts in Ugwolawo District, Kogi State ( $n=105)$

\begin{tabular}{|l|l|l|}
\hline Sources of information & Frequency* $^{*}$ & Percentage \\
\hline Fellow farmers & 105 & 100.0 \\
\hline Village leaders & 20 & 19.0 \\
\hline Extension agents & 3 & 2.9 \\
\hline Radio & 70 & 66.7 \\
\hline Television & 3 & 2.9 \\
\hline Cashew buying agents & 105 & 100.0 \\
\hline
\end{tabular}

*Multiple responds recorded

\subsection{Constraints to Production and Marketing of Cashew Nuts}

Entries in Table 7 show the constraints to production and marketing of cashew nuts in the study area. The results showed that 7 out of the 12 constraints militating against cashew nuts' production in the study area were very severe. These included lack of access to improved post-harvest technology (90\%), inadequate access to improved cashew varieties (89.5\%), poor knowledge of improved agronomic practices $(89.5)$, poor processing facilities $(87.6 \%)$, inadequate capital $(83.8 \%)$, high cost of inputs $(83.8 \%)$ and high pest and disease infestation (81\%) while constraints such as low productivity of existing plantations (91.4\%), difficulty in acquiring land for cashew production (78.1\%) and inadequate labour for cashew farming (55.2\%) recorded low severity. Production constraints with high mean scores included lack of access to improved post-harvest technology $(\mathrm{M}=2.84)$, inadequate access to improved cashew varieties $(\mathrm{M}=2.86)$, poor knowledge of improved agronomic practices $(M=2.85)$, poor processing facilities $(M=2.79)$ and inadequate capital $(M=2.76)$, high cost of inputs $(\mathrm{M}=2.78)$ which could be as a result of lack of government intervention in subsidizing the price of inputs, high pest and disease infestation $(M=2.75)$ which could be due to the high cost of inputs for pest and disease control as well as poor knowledge of pest and disease control for cashew, lack of incentives for cashew production $(\mathrm{M}=2.17)$ and change in climatic condition $(\mathrm{M}=2.05)$. Earlier studies found that $70.0 \%$ and $72.0 \%$ respectively of cashew farmers ranked inadequate capital as the most sever constraintto cashew production [14, 28]. This could be attributed to the difficulty in acquiring loan from the bank due to lack of collateral. Change in climatic condition could be as a result of the seasonal fluctuations in rainfall. The severity in inadequate access to improved cashew varieties, poor knowledge of improved agronomic practices and lack of incentives for cashew production could be due to lack of access to research centres for cashew and poor services of extension agents in the study area, while the severity in lack of access to improved post-harvest technologies and poor processing facility could be attributed to poor government support and policy for cashew nuts' production.

Results in Table 6 also show that low selling price of produce due to lack of pricing policy (81.7\%), poor transportation system (93.3\%), lack of institutional support (91.4\%), unstable prices of nuts (89.5\%), inadequate government policies $(88.6 \%)$ and poor storage facilities $(81 \%)$ constituted very 
severe constraints to marketing of cashew nuts in the study area. The severe constraints included poor marketing networks/channels (75.2\%) inadequate market information (67.6\%) and insufficient buyers (46.7\%), while competition among local buying agents $(79.0 \%)$ and poor quality of cashew nuts $(63.8 \%)$ were not severe to most farmers. The marketing constraints with severe mean scores were poor transportation system $(\bar{x}=2.91)$, lack of institutional support $(\bar{x}=2.87)$, inadequate government policies $(\bar{x}=2.86)$, unstable prices of nuts $(\bar{x}=2.83)$, low selling price of produce due to lack of pricing policy $(\bar{x}=2.78)$, poor storage facilities $(\bar{x}=2.70)$ and inadequate market information $(\bar{x}=2.02)$, which could be due to poor extension service and far location of research centres. The findings corroborate the study of====== who reported that the seasonality nature of cashew nuts production and lack of storage facilities, among others constituted severe problems to cashew nuts marketing [5]. The poor transportation, lack of institutional support, inadequate government policies, low selling price of produce due to lack of pricing policy, poor storage constraints could be due to lack of government intervention in the cashew production and marketing in the study area. This finding is corroborated with a study on factors associated with low yield of cashew in Nigeria where all the farmers indicated poor price of cashew nuts (100\%) and most $(98.3 \%)$ identified inadequate government policy as major factors militating against cashew nuts marketing [27].

This generally implies that there was high level of severity of some constraints to production and marketing of cashew nuts in the study area. Findings also indicated that there is a wide range of constraints militating against the production and marketing of cashew nuts in Ugwolawo District, Kogi State, Nigeria. These could affect the prospects and opportunities in cashew industry.

Table 7. Constraints to Production and Marketing of Cashew Nuts in Ugwolawo District, Kogi State (n=105)

\begin{tabular}{|c|c|c|c|c|}
\hline Constraints & $\begin{array}{l}\text { Very Severe } \\
(\%)\end{array}$ & $\begin{array}{l}\text { Severe } \\
(\%)\end{array}$ & $\begin{array}{l}\text { Not Severe } \\
(\%)\end{array}$ & Mean \\
\hline \multicolumn{5}{|l|}{ Production Constraints } \\
\hline Low Productivity of Existing Plantations & 91.4 & 1.9 & 6.7 & 1.15 \\
\hline $\begin{array}{l}\text { Inadequate Access to Improved Cashew } \\
\text { Varieties }\end{array}$ & 89.5 & 6.7 & 3.8 & 2.86 \\
\hline $\begin{array}{l}\text { Poor Knowledge of Improved Agronomic } \\
\text { Practices }\end{array}$ & 89.5 & 5.7 & 4.8 & 2.85 \\
\hline Inadequate Capital & 83.8 & 8.6 & 7.6 & 2.76 \\
\hline $\begin{array}{l}\text { Lack of Access to Improved Post Harvest } \\
\text { Technology }\end{array}$ & 90.5 & 2.9 & 6.7 & 2.84 \\
\hline Lack of Incentives for Cashew production & 39.0 & 39.0 & 21.9 & 2.17 \\
\hline Change in Climatic Condition & 35.2 & 34.3 & 30.5 & 2.05 \\
\hline $\begin{array}{l}\text { Inadequate Access to Labour for Cashew } \\
\text { Farming }\end{array}$ & 18.1 & 26.7 & 55.2 & 1.63 \\
\hline High Pest and Disease Infestation & 81.0 & 13.3 & 5.7 & 2.75 \\
\hline High Cost of Inputs & 83.8 & 10.5 & 5.7 & 2.78 \\
\hline $\begin{array}{l}\text { Difficulty in Acquiring Land for Cashew } \\
\text { Cultivation }\end{array}$ & 13.3 & 8.6 & 78.1 & 1.35 \\
\hline Poor Processing Facilities & 87.6 & 3.8 & 8.6 & 2.79 \\
\hline \multicolumn{5}{|l|}{ Marketing Constraints: } \\
\hline Inadequate Market Information & 17.1 & 67.6 & 15.2 & 2.02 \\
\hline $\begin{array}{l}\text { Low Selling Price of Produce due to Lack of } \\
\text { Pricing Policy }\end{array}$ & 85.7 & 6.7 & 7.6 & 2.78 \\
\hline Lack of Institutional Support & 91.4 & 3.8 & 4.8 & 2.87 \\
\hline Poor Marketing Networks/channels & 10.5 & 75.2 & 14.3 & 1.96 \\
\hline Poor Transportation System & 93.3 & 4.8 & 1.9 & 2.91 \\
\hline Poor Storage Facilities & 81.0 & 8.6 & 10.5 & 2.70 \\
\hline Insufficient Buyers & 12.4 & 46.7 & 41.0 & 1.71 \\
\hline Poor Quality of Produce (cashew nuts) & 13.3 & 22.9 & 63.8 & 1.50 \\
\hline Inadequate Government Policies & 88.6 & 8.6 & 2.9 & 2.86 \\
\hline
\end{tabular}




\begin{tabular}{|l|l|l|l|l|}
\hline Competition Among Local Buying Agents & 4.8 & 16.2 & 79.0 & 1.26 \\
\hline Unstable Prices of Nuts & 89.5 & 3.8 & 6.7 & 2.83 \\
\hline
\end{tabular}

Mean cut-off point $=2.0$

\subsubsection{Relationship between Awareness and Use of Cashew Agronomic Practices}

The relationship between level of awareness of respondents and their use of cashew agronomic practices was tested using Spearman's rank correlation and the result obtained is presented in Table 8 . The Spearman's correlation coefficient (Rho) was 0.2272 , indicating that the variables have $22.72 \%$ positive relationship among them. The correlation coefficient was significant at 5\% level (prob $>/ \mathrm{t} /$ $=0.0198$ ), indicating that there was a significant relationship between the use of cashew agronomic practices and awareness of the respondents. The null hypothesis is therefore rejected.

\begin{tabular}{|c|c|c|c|}
\hline \multicolumn{3}{|c|}{ AWARE } & \multirow[t]{2}{*}{ USE } \\
\hline AWARE & & 1.0000 & \\
\hline USE & & 0.2356 & 1.0000 \\
\hline Spearmansrio $=$ & \multicolumn{2}{|l|}{0.2272} & \\
\hline \multicolumn{4}{|c|}{ Test of HO: AWARE and USE are independent } \\
\hline \multicolumn{3}{|c|}{ Prob $>/ t=0.0198$} & \\
\hline
\end{tabular}

\subsubsection{Relationship between Use of Agronomic Practices and Level of Production of Cashew Nuts}

Spearman's rank correlation was used to test the relationship between the use of agronomic practices and level of production of cashew and the result is presented in Table 9. It was found that there was $20.02 \%$ positive relationship between the variables $(\mathrm{Rho}=0.2002)$, which was significant at $5 \%$ alpha level (prob/t/=0.0405). The null hypothesis which states that there is no significant relationship between respondents' use of agronomic practices and level of production of cashew nuts is therefore rejected.

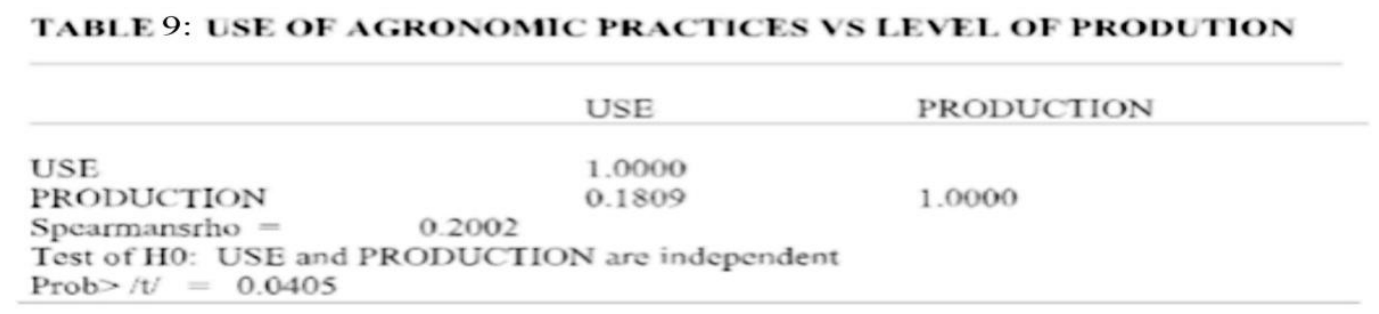

\section{CONCLUSiON}

The study concludes that male farmers with long years of farming experience dominated cashew farming in Ugwolawo District, Kogi State of Nigeria. Overall, the level of production of cashew nuts was low due to a plethora of constraints, including non-utilization of some yield enhancing technologies and poor access to viable markets. This study is important for raising the awareness level of cashew farmers on available improved cashew agronomic practices and marketing channels and stimulating their interest for sustainable management of cashew farms. It can enhance extension workers' choice of communication channels to adopt for proper diffusion of information on cashew improved technologies among farmers a well as encourage policy makers to design and implement realistic policies on cashew production and marketing for enhanced farmers' income and livelihoods.

\section{REFERENCES}

[1] Olife I.C., Jolaso M.A. and Onwualu A.P., Cashew processing for economic development in Nigeria, Agricultural Journal. 8(1), 45-50 (2013).

[2] Akanni K.A. and Adams A.A., Assessment of pricing efficiency and levels of concentration in cashew nuts market in South Western Nigeria. Journal of Agricultural science and Technology. (1), 353-359 (2011).

[3] FAO (2008). Cashew industry and production. Available online @ http://en.wikipedia.org/ wifi/cashew industry-and-production.

[4] Hammed L.A., Adedeji A.R., Asogwa E.U. and Ibriemo O.S., Constraints to cashew production in Nigeria. A paper presented at the cashew stakeholders meeting organized by the African Cashew Aliance (ACA) held at International Institute of Tropical Agriculture(IITA), Ibadan, Nigeria. Pp:20-21 (2007). 
[5] Adejo P.E., Otitolaye J.O. and Onuche U., Analysis of marketing channel and pricing system of cashew nuts in North Central Nigeria, Journal of Agricultural Science. 3(3), 246-248 (2011).

[6] Nugawela P.A. and Oroch R., Cashew sub sector strategic frame work: promoting proper opportunities through commodity and service markers. Department for International Development (UK) Nigeria, (2005).

[7] Adeigbe O.O., Olasupo F.O., Adewale B.D. and Muyiwa A.A., A review of cashew research and production in Nigeria in the last four decades, Academic Journal. 10(5),196-209 (2015).

[8] FAO (2017). Nigeria: Cashew nuts production in quantity. Available online @ www.factfish.com.

[9] FAO .(2007). Food and Agricultural Organization statistic division. Available online @ http://faostat.fao.org/site/336/DesktopDefault.aspx?pageID=336.

[10] Asogwa E.U., Hammed L.A. and Ndubuaku T.C.N., Integrated production and protection practices of cashew (Anacardiumoccidentale) in Nigeria, African Journal of Biotechnology. 17(25), 4868-4873 (2008).

[11] Nayar K.G., Cashew: a crop with unlimited potentials. The cashew. pp:246-248 (1995).

[12] CBN (Central Bank of Nigeria). Annual reports and Statement of account of the year 2005, p:155.

[13] Akanbi O.S.O., Famaye A.O., Ojeniyi S.O., Nduka B.A., Taiwo N., Olasupo F.O., Azeez O.M., Edibo G.O. and Gbemisola D.O., Growth response of cashew seedlings to applied organic fertilizers of animal and plant origin on a degraded soil in Ibadan, South-West Nigeria, International Research Journal of Agricultural Science and Soil Science. 3(3), 93-98 (2013).

[14] Uwagboe E.O., Adeogun S.O. and Odebode S.O., Constraints of farmers in cashew production: A case study of Orire L.G.A of Oyo State, Nigeria, ARPN Journal. 2(9), 27-30 (2010).

[15] Oluyole K.A., Yahaya A.T., Uwagboe E.O., Mokwunye I.U., Agbeniyi S.O., Orisajo S.B., Otunoye A.H., Ndagi I., Shittu T.R. and Aderolu I.A., Constraint in cashew production among cashew farmers in Southwestern Nigeria, International Journal of Science and Nature. 6(3), 329-33 (2015).

[16] Ndagi I., Oduwole O.,TaiwoO.,Muhammed I. and Rahaman S., Socio-economic factors affecting use of information sources among cashew farmers in Niger State, Nigeria, American-Eurasian Journal of Agriculture and Environmental Science. 13(6), 769-773 (2013).

[17] Oladejo, J. A., Profitability and structural analysis of cashew nut market in Oyo State, Nigeria. International Journal of Agricultural Policy and Reasearch. 3(3), 114-221 (2015).

[18] Lawal J.O., Oduwole O.O., Shittu T.R. and Muyiwa A.A., Profitability of value addition of cashew farming households in Nigeria. African Crop Science Journal. 19(1), 49-54 (2011).

[19] National Population Commission (NPC) (2009). 2006 National Population Census Official Gazette (Extraordinary) 94(4), 52.

[20] Ofu LGA Information Book, 2015.

[21] Farayola C.O., Akintonde J.O., Awoyemi S.O. and Akintaro O.S., Economic analysis of cashew nuts marketing among produce buyers in Ogbomosho metropolis of Oyo State, Nigeria. International Journal of Agriculture Innovations and Research. (2),1473-2319 (2013).

[22] Paschal B.N.M., (2013). Analysis of social-economic factors affecting cashew nut production in Ruangwa District, Tanzania.

[23] Adesiji G.B., Omotoesho K.F., Bolarin O. and Aigbauboa P., Assessment of training needs of cashew farmers in Owan East Local Government Area of Edo State, Nigeria, Agrosearch. 12(2), 184-195 (2012).

[24] Wongnaa C.A., Analysis of factors affecting the production of cashew in Wenchi Municipality, Ghana, The Journal of Agricultural Science. 8(1), (2013).

[25] Akor A., Ibitoye S.J. and Ayoola J.B., Analysis of socio-economic characteristics and profitability in cashew nut production in Kogi State, Nigeria, Int'l Journal of Agriculture and Rural development.17(2), 1739-1745 (2014).

[26] Bianca D. and Stefano C., Cashew from seed to market: A review, Agronomy for Sustainable Development, Springer Verlag. 34(4), 753-772 (2014).

[27] Agbongiarhuoyi A.E., Ugwagboe E.O., Ibiremo O.S., Olasupo F.O. and Aigbekaen E.O., Assessment of Factors Associated with Low Yield of Cashew among Farmers in Growing Areas in Nigeria, American Journal of Experimental Agriculture. (6), 258-266 (2015).

[28] Krishnal T., Factors affecting the production of cashew in Batticoloa District, Social Science and Humanity. 319-325 (2014).

Citation: Agada, et.al., (2020). "Cashew Nuts Production and Marketing among Farmers in Ugwolawo District, Kogi State, Nigeria”. ", International Journal of Research Studies in Agricultural Sciences (IJRSAS), 6(5), pp. 1-10. DOI: http://dx.doi.org/10.20431/2454-6224.0605001

Copyright: (C) 2020Authors. This is an open-access article distributed under the terms of the Creative Commons Attribution License, which permits unrestricted use, distribution, and reproduction in any medium, provided the original author and source are credited. 